\title{
THE EFFECTIVENESS OF INNOVATION PROJECTS IN POLISH INDUSTRY
}

\author{
Jan Zwolak \\ Jan Zwolak Ph.D. \\ University of Economics and Innovation \\ Institute for the Application of Quantitative Methods in Economics \\ ul. Projektowa 4, 20-209 Lublin, Poland \\ jan.zwolak@wsei.lublin.pl \\ Article info \\ Paper category: Review \\ Received: 26.8.2016. \\ Accepted: 14.3.2016. \\ JEL classification: $\mathrm{C}_{1} 3, \mathrm{C}_{51}, \mathrm{E}_{2} 3, \mathrm{~L} 16$
}




\begin{abstract}
The objective of the study was to determine the dependency of the net income from the sales of new and significantly modernised products on the expenditure on (1) marketing and staff training as well as on the expenditure on (2) land, buildings and structures; machinery, technical equipment and tools; and means of transportation within the scope of product and process innovations in Polish industry in 2010. Furthermore the study was intended to determine the effectiveness of the abovementioned expenditure aggregated to descriptive variables ( 1 and 2). In the study, the correlation and regression methods as well as the least squares method was applied. The estimation resulted in the determination of functional dependency of net sales income on the expenditure on marketing and staff training (0.5040) as well as on the expenditure on land, buildings and structures; machinery, technical equipment and tools; and means of transportation (0.8064) in the field of innovative processes in industry. The net sales income increased more than proportionally relative to the combined effect of the aforementioned expenditure (1.3104). The total increase in the aforementioned expenditure by $10 \%$ resulted in the increase in net sales income by $13.1 \%$. The determined power regression model may have practical implications for the economic evaluation of expenditure in innovative processes in Polish industry in the future, as well as for the forecast (prediction). The expenditure application in innovative processes may also have social implications connected to the increase in the value-in-use of products and with the increase in the social efficiency of work in Polish industry.
\end{abstract}

\title{
Keywords:
}

innovation process, correlation and regression, effectivenes 


\section{INTRODUCTION}

Innovation in a broader aspect comes down to a model conception where innovations are the function of knowledge, skills, entrepreneurship and creativity. This model illustrates the determinants of innovative developments in economic systems.

Currently, attempts are being made to create a general theory of innovation ${ }^{1}$ which would cover the entire innovative process in its material, functional and interdisciplinary meaning. ${ }^{2}$ Such a theory would also constitute a theoretical directive for the needs of identification, measurement and economic assessment of innovations. ${ }^{3}$

Therefore various partial theories describe a system for measuring innovations in products and processes, techniques and technology, marketing activities and training applications which occur within the system. Innovations within the scope of products help to increase sales and the related margins while innovations which improve processes result in an increase in work efficiency and build cost advantage over competitors. ${ }^{4}$

The author hopes that the empirical studies in the scope of product and process innovations, using the Cobb-Douglas model, as presented below, will contribute to the creation of the general theory of innovation (model = theory). In the future, the author will conduct studies using other classifications of innovative expenditure streams.

The objective of this study was to determine the dependency of the net income from sales on the expenditure on marketing and staff training as well as on the expenditure on land, buildings and structures; machinery, technical equipment and tools; and means of transportation within the scope of product and process innovations in Polish industry in 2010. Furthermore the study was intended to determine the effectiveness of the abovementioned expenditure aggregated to descriptive variables.

The underlying hypothesis in the study assumes that the mean and marginal productivity of expenditure on marketing and staff training, and of the expenditure on land, buildings and structures; machinery, technical equipment and tools; and means of transportation remained in the rational economic zone in Polish industry in 2010. If such dependence occurs, it will indicate an adequate level of proportions among these innovative expenditures.

1 A complex set of innovation measures causes enterprises to adapt better to the conditions of the global external environment, says Pachura (2012).

2 Further, commerce liberalisation indicates significance of other factors for the increase made like other policy, investments and institutions, as indicated by Winters (2004).

3 The role of innovations as a growth driver in market economy has been emphasized by Janasz et al. (1993).

4. Astrong potential of Poland as defined by Pechon (2007) necessitates development of scientific research and new technologies. 


\section{MATERIAL AND METHODS}

The source of empirical data was the Statistical Yearbook of the Voivodeships, the Central Statistical Office [GUS] in Warsaw, 2011. It enabled the identification of data determining the process of innovations in industry, i.e. both expenditure and effects (objectives) constituting the elements of an economic account. In addition, expenditure (costs) and effects have an impact on each other; for this reason they were quantified as to their value and included in the account of innovation effectiveness on the scale of mesoeconomics and of the whole country. The variables which define the development of market transactions and net sales income were grouped according to production factors and innovation initiatives.

Variables aggregated to the multiple curvilinear function model were selected by applying logarithm correlation coefficients. Numerical calculations were performed with Statistica 9. o software.

\section{RESULTS OF THE STUDY}

The statistical characteristics of the features of the adopted recognition of aggregated variables were determined by use of the arithmetic mean, range and coefficient of variation; they are presented in Table 1.

Table 1.: Statistical Characteristics of Variable Features Relating to Product and Process Innovations in The Polish Industry in 2010 (Current Prices)

\begin{tabular}{|c|c|c|c|c|c|c|}
\hline No. & Specification* & Symbol & $\begin{array}{c}\text { Unit of } \\
\text { Measurement }\end{array}$ & $\begin{array}{c}\text { Arithmetic } \\
\text { Mean }\end{array}$ & $\begin{array}{c}\text { Range } \\
\text { min. - } \\
\text { max. }\end{array}$ & $\begin{array}{c}\text { Coefficient } \\
\text { of Variation } \\
(\%)\end{array}$ \\
\hline 1. & $\begin{array}{r}\text { Net income } \\
\text { from the sales } \\
\text { of new and } \\
\text { modernised } \\
\text { products }\end{array}$ & Y & million PLN & 6443.64 & $\begin{array}{r}609.03- \\
24965.20\end{array}$ & 122.05 \\
\hline 2. & $\begin{array}{r}\text { Expenditure } \\
\text { on marketing } \\
\text { of new and } \\
\text { modernised } \\
\text { products and } \\
\text { on staff training } \\
\text { regarding } \\
\text { innovative } \\
\text { activity }\end{array}$ & $\mathrm{x} 1$ & million PLN & 32.32 & $\begin{array}{r}1.7^{-} \\
15^{1.4}{ }^{-}\end{array}$ & 125.38 \\
\hline
\end{tabular}




\begin{tabular}{|c|c|c|c|c|c|c|}
\hline No. & Specification & Symbol & $\begin{array}{c}\text { Unit of } \\
\text { Measurement }\end{array}$ & $\begin{array}{l}\text { Arithmetic } \\
\text { Mean }\end{array}$ & $\begin{array}{l}\text { Range } \\
\text { min. - } \\
\text { max. }\end{array}$ & $\begin{array}{c}\text { Coefficient } \\
\text { of Variation } \\
(\%)\end{array}$ \\
\hline 3. & $\begin{array}{r}\text { Expenditure } \\
\text { on buildings } \\
\text { and structures; } \\
\text { machinery, } \\
\text { land, technical } \\
\text { equipment } \\
\text { and tools and } \\
\text { means of } \\
\text { transportation }\end{array}$ & x2 & million PLN & $1009 \cdot 48$ & $\begin{array}{r}177.70^{-} \\
4344.80\end{array}$ & 114.11 \\
\hline 4. & $\begin{array}{r}\text { Expenditure on } \\
\text { acquisition of } \\
\text { technology }\end{array}$ & $\mathrm{x} 3$ & million PLN & 94.16 & $\begin{array}{r}3.20- \\
705.00 \\
\end{array}$ & 193.02 \\
\hline
\end{tabular}

Source: Statistical Yearbook of Voivodeships, Central Statistical Office (GUS) in Warsaw, 2011. Author's calculations.

*Data relate to economic entities where the number of employed persons exceeded 49 . Data were processed on a voivodeship level.

The mean value of the net income from sales (Table 1.) of new and significantly improved products in industry, in a typical voivodeship, was 6443.64 million PLN, and the range of net income indicates a large variation between voivodeships. This also confirms the internal variability within net income from innovative processes in 2010. It was close to the internal variability of expenditure on the marketing of new and improved products and staff training in innovative activity in industry. The effects of innovative processes are characterised by their uneven distribution over time. ${ }^{5}$

The expenditure on marketing of new and improved products and staff training was designed to maximise net income while keeping costs at a minimum and providing the highest customer satisfaction. New and significantly improved products were also associated with the implementation of more sophisticated marketing methods; this has been described by normative theories of marketing. Their mean level in a voivodeship was the lowest within the analysed expenditure data. The extreme values of expenditure on marketing and staff training were also the lowest ones while their distribution in industry and voivodeship was similar to those obtained from net income transactions.

Expenditure on land, buildings and structures; machinery, technical equipment and tools and means of transportation were primarily process innovations connected with the improvement in production and distribution methods within the scope of products and services in industry. In addition to land expenditure, these were the typical technical (material and functional) innovations. Among the variables shaping the variability of net income in industry in an average voivodeship, these were

5 This results in the situation where research and development are expensive and do not always bring the expected results, explain Tomke and von Hippel (2002). 
characterised with the highest level and range. Their internal variability, however, was the lowest.

The technological novelty of a given solution, including the expenditure on technology acquisition, should be examined in the context of its results (benefits) if it is to participate in the process of technological innovation. ${ }^{6}$ It is difficult, therefore, to quantify the benefits of the purchased ready-made technology in the form of documentation and rights. It was related to both the accuracy and reliability of the measurement. Although their level in industry and voivodeship was the lowest of the examined expenditures, their range was expanded and their internal differentiation was the highest. For this reason, the purchased ready-made technologies of documentation and rights may have exerted a positive or negative impact which determines the positive or negative development of innovation. As the regression coefficient determined for them was at a significance level exceeding 0.05 , they were brought to the constant of the equation (a).

The literature sources mention the opinion that the market incentives for innovation applications are too weak. ${ }^{7}$ Thus, the assessment of the innovation effectiveness was of importance - the assessment of the extent to which they contributed to the increase of effectiveness of the net sales income in industry in Poland in 2010.

A random examination of the random component distribution was performed by a graphical analysis which confirmed the verification of the hypothesis, assuming the validity of the choice of analytical form of the function model (Table 2). The Shapiro-Wilk test was applied to the examination of the random component normality. The values resulting from calculations, when compared with critical values at a significance level of 0.05 did not justify the rejection of the hypothesis that the distribution of the random component was normal. Autocorrelation was examined using the Durbin-Watson test; based on its results, the lack of autocorrelation of the random component was determined at the significance level of 0.05 . The hypothesis of the random component homoscedasticity was verified by the Goldfeld-Quandt test. At the adopted level of significance of 0.05 , the read critical value of Snedecor's F-distribution exceeded the calculated value; as a result, there was no basis for the rejection of the hypothesis of the random component homoscedasticity. ${ }^{8}$

6 Assigning the top priority to expenditure on research and development from the state budget and enterprises is a key issue in the Polish economic policy, emphasizes Dworak (2010).

7 As explained by Frost (2004), this also contributes to the situation where over long term concepts coexist and concentrate investment projects with security short-term.

8 Examples of application of significance tests for assessment of multiple regression model parameters have been presented by Aczel (1989 and 1993). 
Table 2.: Exponential Regression Of Net Income From The Sale Of New And Significantly Improved Products (Y) From The Expenditure On Marketing And Staff Training ( $\mathrm{X}_{1}$ ) And Investment In Land, Buildings And Structures, Machinery, Technical Equipment And Tools And Means Of Transportation $\left(\mathrm{X}_{2}\right)$ Within The Field Of Product And Process Innovations In The Polish Industry In 2010

\begin{tabular}{|c|r|r|r|r|r|r|r|r|r|}
\hline$a^{*}$ & \multicolumn{2}{|c|}{$\begin{array}{c}\text { Regression } \\
\text { Coefficients }\end{array}$} & \multicolumn{2}{|c|}{ Standard error } & \multicolumn{2}{|c|}{ tTest } & \multicolumn{2}{|c|}{$\begin{array}{c}\text { Level of } \\
\text { Significance }\end{array}$} & \multicolumn{1}{c|}{$\mathbf{R}_{2}$} \\
\hline & $\mathrm{x} 1$ & $\mathrm{x} 2$ & $\mathrm{x1}$ & $\mathrm{x} 2$ & $\mathrm{x} 1$ & $\mathrm{x} 2$ & $\mathrm{x} 1$ & $\mathrm{x} 2$ & \\
3.8432 & 0.5040 & 0.8064 & 0.24 & 0.37 & 2.02 & 2.17 & 0.05 & 0.05 & 0.83 \\
\hline
\end{tabular}

Source: The Statistical Yearbook of Voivodeships, The Central Statistical Office (GUS) in Warsaw, 2011. Numerical calculations.

* a - constant of equation (delogarithmized); it also includes the mean increase in the value of expenditure on the acquisition of ready-made technology in the form of documentation and rights (brought to the constant of the equation), the regression coefficient of which was determined at a significance level exceeding 0.05 (5\%).

The tabular convention comprises the equation of power regression together with its statistical assessment (Table 2.). The data of Table 2. present the functional dependency of the net income from the sale of new and improved products (Y) on the expenditure on the marketing of new and improved products and staff training regarding innovative activity (xı) and on the expenditure on land, buildings and structures; machinery, technical equipment and tools, and means of transportation (x2). The aforementioned aggregated variables ( $\mathrm{x} 1$ and $\mathrm{x}_{2}$ ) explained to $83 \%$ the variability of the net income from sale of new and improved products in industry. This was a high explanation. The strength of association, described with the correlation coefficient $(\mathrm{R})$, between net sales income and expenditure on marketing and staff training and expenditure on land, buildings and structures; machinery, technical equipment and tools, and means of transportation amounted to $91 \%(=\mathrm{R})$. The standard errors of the function's parameters (regression coefficients) were below $50 \%$ of their absolute values. The t test values, in turn, were several times higher than the values of the regression coefficients (parameters), and the significance level of regression coefficients amounted to 0.05 . The aforementioned statistical assessments of the regression coefficients (parameters) indicate the possibility of applying them to the econometric assessment of the variability of the net income from the sale of new and improved products in industry in 2010.

Regression coefficients, the function parameters ${ }^{9}$ at $\mathrm{x} 1$ and $\mathrm{x} 2$ determine the flexibility (flexibility coefficients) of the net sales income in respect of the expenditure on marketing and staff training and of the expenditure on land, buildings and structures; machinery, technical equipment and tools; means of transportation within the scope of innovations in industry. Therefore, the regression coefficients (function

9 The Cobb-Douglas production function allows for identification of the role of production factors, explain Zimkova and Barochovsky (2007). 
parameters) are, in other words, the flexibility coefficients. ${ }^{10}$ In the power function, the exponents of explanatory variables are interpreted as the flexibilities of the endogenous variable in relation to appropriate factors. A flexibility coefficient determines the mean percentage change (increase or decrease) in a dependent variable when the xj factor increases by $1 \%$, assuming that the remaining factors are constant. ${ }^{11}$

The flexibility of the net sales income (Table 2.) was higher than the expenditure on land, buildings and structures; machinery, technical equipment and tools and means of transportation within the scope of innovations (0.8064) than for the expenditure on marketing and staff training (0.5040). The association between the regression coefficients (flexibility coefficients) shows that the net sales income in relation to the expenditure on marketing and staff training was 1.6 times less than in relation to the investment in land, buildings and structures; machinery, technical equipment and tools, and means of transportation. Based on the sum of flexibility coefficients (powers) which is higher than unity (1.3104) the net income from the sale of new and improved products in relation to the combined impact of expenditure on marketing and staff training, land, buildings and structures; machinery, technical equipment and tools, and means of transportation increased more than proportionally. The aggregate increase in expenditure on marketing and staff training; land, buildings and structures; machinery, technical equipment and tools, and means of transportation by 10\% resulted in an increase of net income from the sale of new and improved products amounting to $13.1 \%$. Based on the impact proportion (sum of flexibilities $=100 \%$ ), it can be calculated that the impact of expenditure on marketing and staff training amounted to $38.46 \%$ and of the expenditure on land, buildings and structures; machinery, technical equipment and tools; and means of transportation - to $61.54 \%$.

The theory of technical development assumes, inter alia, the need to perform the econometric assessment of objectives (net income from sale) and causes (costs). Despite the fact that the elements of account, referred to above, belong to the same model, the participation of the examined factors in the growth in net income from the sale of new and significantly improved products was not identical. The important active elements interacting in the creation of the level of net sales income included the expenditure on marketing and staff training from the innovative activity in industry. For this reason it was necessary to determine, within the range of expenditure on marketing and staff training, respective values of the net income from sale. They were then used to determine the average and marginal productivity in industry, presented in Table 3 .

10 As explained by Solow (1956), they are Y flexibilities towards $x_{1}$ and $x_{2}$, and according to the J. B. Clark's marginal productivity theory, they are shares of outlays of those factors $\left(x_{1}\right.$ and $\left.x_{2}\right)$ for product (net sales income).

11 As stated by Aczel (1989 and 1993) it has to be remembered that it is a regression relation and not cause relation (Y depending on $x_{1}$ and $x_{2}$ ). Causality is difficult to define and even more difficult to prove. 
Table 3.: Mean and Marginal Productivity of Expenditure on Marketing and Staff Training in Innovative Activity in Polish Industry in 2010

\begin{tabular}{|c|c|c|}
\hline \multirow{2}{*}{$\begin{array}{l}\text { Expenditure on marketing } \\
\text { and staff training, million } \\
\text { PLN }(x\urcorner)\end{array}$} & \multicolumn{2}{|c|}{ Productivity } \\
\hline & mean, PLN/ PLN & marginal, PLN/ PLN \\
\hline 20.41 & $227 \cdot 77$ & 114.79 \\
\hline 39.13 & 164.95 & 83.13 \\
\hline 57.84 & 135.88 & 68.48 \\
\hline $7^{6} \cdot 55$ & 118.24 & $59 \cdot 59$ \\
\hline 95.26 & 106.08 & $5^{3.47}$ \\
\hline 113.98 & 97.06 & 48.92 \\
\hline 132.69 & 90.01 & 45.36 \\
\hline 151.40 & 84.31 & 42.49 \\
\hline
\end{tabular}

Source: Author's calculations based on data presented in Tables 1. and 2.

The mean and marginal productivity (Tables 3. and 4.) in relation to each other was proportional through the flexibility constant of the net sales income related to the expenditure on marketing and staff training and to the expenditure on land; machinery, technical equipment and tools; and means of transportation in industry (Tables 3. and 4.).

The mean productivity (Table 3.) was two times higher as compared with the marginal productivity of expenditure on marketing and staff training. The decrease in mean and marginal productivity with the increase in expenditure on marketing and staff training took place in the ratio of $2: 1$. In turn, the increase in expenditure on marketing and staff training within the scope of innovations exceeding 57.83 million PLN was related to an increasingly smaller decrease in their mean and marginal productivity. It explains the fact that as the expenditure on marketing and staff training grew their and marginal productivity remained in the same relationship and demonstrated increasingly smaller drops; indicating an effective allocation.

Marginal productivity decreased at a slower rate (Table 3.); it also affected the decrease in mean productivity, also at a slower rate, while the net income from the sale of new and modernised products grew but its growth rate approached zero. All this took place in the rational economy zone. The decrease in the mean and marginal productivity of expenditure was connected with the economic effectiveness of the increase in equipping the industrial enterprises with fixed and current assets.

The character of the expenditure on land, buildings and structures; machinery, technical equipment and tools; and means of transportation in the innovation process varied from that of expenditure on marketing and staff training within the scope of innovations. New Constructions of buildings and structures; machinery, technical equipment and tools; and means of transportation presented the typical technical, therefore material innovations. This process came to an end with the implementa- 
tion of a new innovation. ${ }^{12}$ The complexity of the innovation process, and the period when the innovation is considered a novelty, hinder the unambiguity of the economical assessment of technical innovation. EU recognises an innovation (implementation) as a new if it functions on the market up to 3 years.

Mean and marginal productivity (Table 4.) of land, buildings and structures; machinery, technical equipment and tools; and means of transportation showed relative stability since the mid-range of the value of this expenditure and the difference between the two categories did not exceed 1 PLN/ PLN. This difference constituted ca $20 \%$ of their mean productivity. The closeness of mean productivity to marginal productivity and the like character of their decrease indicate the relative stability of allocation of the expenditure being the carriers of technical innovation in industry.

Table 4.: Mean and Marginal Productivity of Expenditure on Land, Buildings and Structures; Machinery, Technical Equipment and Tools, and Means of Transportation in Polish Industry in 2010

\begin{tabular}{|c|c|c|}
\hline \multirow{2}{*}{$\begin{array}{c}\text { Expenditure on land; } \\
\text { buildings and structures; } \\
\text { machinery, technical } \\
\text { equipment and tools; and } \\
\text { means of transportation, in } \\
\text { million PLN }\left(x_{2}\right)\end{array}$} & \multicolumn{2}{|c|}{ Productivity } \\
\hline & mean, PLN/ PLN & marginal, PLN/ PLN \\
\hline 698.59 & 6.23 & 5.03 \\
\hline 1218.59 & 5.60 & $4 \cdot 5^{1}$ \\
\hline 1738.59 & 5.23 & 4.21 \\
\hline 2258.59 & 4.97 & 4.01 \\
\hline $277^{8} .59$ & $4 \cdot 77$ & 3.85 \\
\hline 3298.59 & 4.62 & $3.7^{2}$ \\
\hline 3818.59 & 4.49 & 3.62 \\
\hline 4338.59 & 4.38 & $3.5^{3}-r$ \\
\hline
\end{tabular}

Source: Author's calculations based on data presented in Tables 1. and 2.

The productivity decreased causing a drop in average productivity of technical innovation carriers $\left(x_{2}\right)$, albeit at a slower rate, whereas the net income from the sale of new and modernised products grew, but the growth rate approached zero. Just like in the case of the expenditure referred to above, the productivity of capital investment in land, buildings and structures; machinery, technical equipment and tools; and means of transportation remained in the rational economy zone.

The study conducted in 2007 shows that the flexibility of sold production was 1.4 times lower than the flexibility of net sales income (2010) in relation to techni-

12 The influence of politics on effectiveness and mobilization of resources when investing in fixed assets has been confirmed by Bassanini and Scarpetta (2001). 
cal innovation expenditure, while the mean and marginal productivity was: over 3 times and over 2 times [lower] in 2007. ${ }^{13}$ Despite the fact that in 2010 the flexibility of net sales income in relation to technical innovation expenditure was higher, the narrowed range of expenditure demonstrated lower mean and marginal productivity of this expenditure in 2010 . This was connected with the gradual decrease in innovation expenditure in industry occurring between the compared years.

An examination of the growth rate of expenditure on innovations in machinery, technical equipment and tools and means of transportation shows that in Lubelskie Voivodeship in 2007 it amounted to $50 \%$, while in respect of buildings, structures and land $-10.53 \%$. This indicates a differentiation of innovation expenditure applications in industry in the Polish voivodeships ${ }^{\mathbf{1 4}}$; the above is confirmed by data presented in Table 1.

The profitability of innovative products and processes has to take into account the requirements of universality (including the cost-efficiency of the expenditure resulting from the principle of rational economy), the correlation between subjects and time and of the assessment of purchase and sale (transaction) results. The costintensity of the net sales income within the range of expenditure on marketing and staff training is presented in Table 5 .

Table 5.: Cost-Intensity of the Net Sales Income in Relation to the Expenditure on Marketing and Staff Training in Polish Industry in 2010

\begin{tabular}{|r|r|}
\hline Net sales income, in million PLN & $\begin{array}{c}\text { Cost-intensity of the net sales income } \\
\text { PLN/ PLN }\end{array}$ \\
\hline 4649.273 & \\
$645^{3} \cdot 486$ & 0.0044 \\
7858.705 & 0.0061 \\
9051.192 & 0.0074 \\
10105.880 & 0.0085 \\
11061.890 & 0.0094 \\
11942.730 & 0.0103 \\
12763.820 & 0.0111 \\
& 0.0119 \\
\hline
\end{tabular}

Source: data presented in Table 3. and calculations based on Table 2.

The data presented in Table 5 . goes on the assumption that creative marketing and staff training have very little impact on 1 PLN of the value of net sales income even when it grew within the range of this expenditure. This explains the fact that innovative products are not involved in the expenditure in industry referred to above. It may

13 Results of econometric research into the intensity of innovations in the output sold by Polish industry in 2007 have been presented by Zwolak (2010).

14. Example: the research into changes in research and development activity (R\&D) and innovation activity in the Lubelskie Voivodeship in Poland that has been conducted by Zwolak and Tarkowski (2013). 
have been related to the higher worth of these products. Also, the cost-intensity of the net sales income within the range of expenditure on land; buildings and structures; machinery, technical equipment and tools; and means of transportation (Table 6.) demonstrated relative stability when tnet sales income grew.

Table 6.: Cost-Intensity of the Net Sales Income According to Expenditure on Land, Buildings and Structures; Machinery, Technical Equipment and Tools, and Means of Transportation in The Polish Industry in 2010

\begin{tabular}{|r|rr|}
\hline $\begin{array}{c}\text { Net sales income } \\
\text { in million PLN }\end{array}$ & & $\begin{array}{c}\text { Cost-intensity of the net sales income } \\
\text { PLN/ PLN }\end{array}$ \\
\hline & 4355.582 & 0.1604 \\
6821.838 & & 0.1786 \\
& 9085.756 & 0.1914 \\
& 11220.200 & 0.2013 \\
13260.690 & 0.2095 \\
& 15228.120 & 0.2166 \\
17136.140 & 0.2228 \\
18994.34 .0 & 0.2284 \\
\hline
\end{tabular}

Source: data presented in Table 4. and calculations based on Table 2.

At the maximum level of net sales income, the impact of the aforementioned technical innovation expenditure on 1 PLN of net sales income in industry amounted to ca $23 \% ; 5$ which is not a significant amount if we assume that from the functional point of view, a whole machine or means of transportation takes part in the innovation process during the transformation of investment into new products and implementing new production method.

\section{SUMMARY AND CONCLUSIONS}

The conducted studies enable the presentation of the following conclusions:

Expenditure on marketing and staff training, land, buildings and structures; machinery, technical equipment and tools, and means of transportation accounted for $83 \%$ of the variability of net income from the sale of new and modernised products in industry $\left(\mathrm{R}^{2}\right)$. This was a high explanation. At the same time, the strength of association described with the correlation coefficient between the net sales income and expenditure on marketing and staff training and investment in land, buildings and structures; machinery, technical equipment and tools; and means of transportation amounted to $9_{1} \%(=\mathrm{R})$.

Net income from the sale of new and modernised products as related to the combined effect of the expenditure on marketing and staff training and of expendi-

15 The technical dependencies and their data limit the options of productivity measurement for the sector, declares Nin et al. (2003). 
ture on land, buildings and structures; machinery, technical equipment and tools; and means of transportation grew more than proportionally (1.3104). The total increase in the aforementioned expenditure by $10 \%$ resulted in an increase in the net income from the sale of new and modernised products by $13 \%$.

As the expenditures on marketing and staff training grew, their mean and marginal productivity maintained the same relationship and demonstrated an increasingly smaller decrease which indicates their effective allocation. At the same time, the investment in land, buildings and structures; machinery, technical equipment and tools; and means of transportation showed relative stabilisation starting from the half of values within the range of this expenditure and the difference between the examined categories did not exceed 1 PLN/ PLN (20\%). The identical character of decreases and the approximate values of mean and marginal productivity indicate the effective allocation of expenditure of a typical innovation character that the aforementioned expenditures have. Differences in the productivity of these investments result from their intensity (level), but also from the material structure of this expenditure in innovative processes. The mean and marginal productivity of the innovation expenditure referred to above remained in the rational economy zone.

The cost-intensity (cost-effectiveness of expenditure or effectiveness of the net sales income) of new and modernised products in industry was higher in relation to the expenditure on land, buildings and structures; machinery, technical equipment and tools; and means of transportation. This effectiveness depended on the relationship of the analysed expenditure (combinations), as well as on the performance (cost effectiveness) of the production factors they represented and the function they fulfilled in the process of innovation.. Technical innovations meant the technical knowledge used for the first time in a new combination, therefore having a specified relationship with other expenditure. In turn, the cost-intensity of net sales income as related to the expenditure on marketing and staff training was very low (minimal) due to the distinct character of the interactions related to the product-market relationship (transaction) which was associated with the differing profitability of these expenditures.

In the course of the conducted studies relating to the character of the study subject, the hypothesis that the mean and marginal productivity of expenditure on marketing and staff training and of the expenditure on land, buildings and structures; machinery, technical equipment and tools; and means of transportation remained in the zone of rational economy of innovative expenditures in Polish industry in 2010 was confirmed. 


\section{REFERENCES:}

Aczel, A. D., "Complete Business Statistics", Second Edition, Irwin, Burr Ridge, Illinois, (1989 and 1993) 5-997

Bassanini, A. and Scarpetta, S., "The driving forces of economic growth: panel data evidence for the OECD countries", OECD Economic Studies. II, 33, (2001): 9

Dworak, E., "Evolution of the Polish Innovation Policy", Comparative Economic Research.12(4), (2010): $121-132$

Frost, F. M., "Value orientations: impact and implications in the extension of complex farming systems", Australian Journal of Experimental Agriculture. 4. (4), (2004), $5^{11-517}$

Janasz, W., Gołębiowski, M., Grabiec, W., Łukasik, W. and Niewiński, A., ”Innowacje jako czynnik rozwoju przedsiębiorstwa w gospodarce rynkowej", Wydawnictwo Naukowe Uniwersytetu Szczecińskiego. Szczecin, (1993)

Nin, A., Amdt, C., Hertel, T. W. and Preckel, P. V., "Bridging the Gap between Partial and Total Factor Productivity Measures Using Directional Distance Functions". American Journal of Agricultural. 85(4), (2003): 928

Pachura, A., "Innovation theory: an epistemological aspects". Polish Journal of Management Studies. 5, (2012): 133

Pechon, D., "Innowacje w Polsce", Luxemburger Wort. 11. 08 ( 2007)

Solow, R., "A Contribution to the Theory of Economic Growth", Quarterly Journal of Economics. 7०(1), (1956): 65-94

Tomke, S. and von Hippel, E., "Customers as Innovators. A New Way to Create Value", Harvard Business Reviev. April (2002): 74-81

Winters, L. A., "Trade Liberalisation and Economic Performance: An Overviev", Economic Journal. 114, $49^{3},(2004): \mathrm{F}_{4}$

Zimkova, E. and Barochovsky, J., "Estimation of potential product and output gap in slovak conditions", Politicka ekonomie. 4, (2007): $47^{3-4,84}$

Zwolak, J.,"Intensywność innowacji produkcji sprzedanej w przemyśle Polski", Zeszyt Naukowy Wyższej Szkoły Humanistyczno-Ekonomicznej im. Jana Zamoyskiego z siedzibš w Zamościu. Zamość, (2010): 98-105

Zwolak, J. and Tarkowski, K., "Zmiany w działalności badawczej i rozwojowej oraz innowacyjnej w województwie lubelskim", Zeszyty Naukowe WSEI seria Ekonomia. Lublin. 6(1), (2013): 223-244 